Article

\title{
Annual Abundance and Population Structure of Two Dung Beetle Species in a Human-Modified Landscape
}

\author{
Julliana W. Barretto ${ }^{1}\left(\mathbb{D}\right.$, Carlos A. Cultid-Medina $^{2, *}{ }^{-1}$ and Federico Escobar ${ }^{1, *(\mathbb{C})}$ \\ 1 Red de Ecoetología, Instituto de Ecología, A.C., Carretera antigua a Coatepec 351, El Haya, Xalapa C.P., \\ Veracruz 91070, Mexico; barrettojulliana@gmail.com \\ 2 Red de Diversidad Biológica del Occidente Mexicano, Instituto de Ecología, A.C.-Centro Regional del Bajío, \\ Av. Lázaro Cárdenas No. 253, Col. Centro, Pátzcuaro C.P., Michoacán 61600, Mexico \\ * Correspondence: carlos.cultid@inecol.mx (C.A.C.-M.); federico.escobarf@gmail.com (F.E.)
}

Received: 6 November 2018; Accepted: 27 December 2018; Published: 28 December 2018

\begin{abstract}
Population studies are essential for understanding different aspects of species' biology, estimating extinction probability, and determining evolutionary and life history. Using the mark-recapture method, we studied the abundance and population structure of dung beetle species (Deltochilum mexicanum and Dichotomius satanas) over one year in a human-modified landscape in Mexico. We captured 1960 individuals with a net recapture rate of $11 \%$. Deltochilum mexicanum had a higher rate of recapture (14\%) than Dichotomius satanas (5\%). Annual variation in abundance was similar for both species, with maximum abundance occurring in summer and a marked reduction during winter. Deltochilum mexicanum was dominant inside the forest, and its abundance was influenced by vegetation cover, temperature, and humidity. Dichotomius satanas was more frequent outside the forest, and none of the considered environmental variables affected its abundance. The adult sex ratio of Deltochilum mexicanum was female-biased, whereas that of Dichotomius satanas was male-biased. The maximum estimated population size was similar for both species, but Deltochilum mexicanum had a higher number of new individuals and survival rate. Since species with different biological attributes presented a similar pattern of abundance and population structure, we conclude that environmental conditions are the main regulator of dung beetle populations in the human-modified landscape.
\end{abstract}

Keywords: cloud forest; Cormack-Jolly-Seber; mark-recapture; Scarabaeinae; seasonality

\section{Introduction}

Population structure and dynamics result from the interaction between species' life-history traits and the environmental characteristics of their habitats. In general, any demographic parameters relevant for population size (age structure, sex ratio, longevity, and survival rate, among others) can be used to evaluate population dynamics and structure [1-3]. Both density-independent factors, such as environmental conditions, and density-dependent factors, such as the rate of natality, mortality, and migration, are determinants of population size. Likewise, population size is regulated by the magnitude of intraspecific interactions (e.g., search for mates, parental care, and territorial defense) and interspecific interactions (e.g., competition for resources, parasitism, and depredation) [1,3]. Therefore, understanding the causes of temporal and spatial variation in the number of individuals in a population is important for elucidating the mechanisms that structure populations. In this way, it is possible to adequately evaluate the vulnerability of species to the modification of environmental conditions at both a local and landscape scale [4-6].

An extensive literature has examined the seasonality of poikilothermic organisms like insects and has also documented the large diversity and complexity of morphological, physiological, and 
behavioral adaptations that enable such organisms to endure seasonal adversity (e.g., low temperatures and drought) [7-9]. Several variables, especially temperature and humidity, are considered determinants of the life cycle, development rate, and demographic structure of insects [10-12]. Generally, in tropical regions with little seasonal variation, population size and structure are expected to be similar throughout the year $[13,14]$. Species often reproduce year-round and present a multivoltine reproductive behavior with generational overlap and relatively stable population size over time [15]. However, according to Wolda (1988) [7], this does not necessarily mean that temporal variations are not present in populations of tropical regions [8]. On the other hand, in markedly seasonal environments (temperate, arid, or semi-arid regions), the population structure of species is expected to change throughout the year and to be synchronized with changes in climatic conditions and resource availability [15]. This results in fluctuations in the entry and exit of individuals in a population and, consequently, variations in population size [13].

In addition to temporal changes, insect population size and structure vary in space [16]. For example, at the landscape scale, differences in vegetation structure, microclimate, and resource supply may create different environmental conditions for individuals of the same population [17]. The vast majority of insects show variation in life-history traits at the population level depending on environmental conditions. Changes may be observed in the period of diapause, pupal size, the start of the breeding season, or in the distribution of adults among different habitat types [18,19]. In turn, population studies have shown that landscape characteristics can regulate rates of fertility and survival, which also depend on population density and the quality of available habitats. As a result, differential population growth rates and persistence may be evident at the landscape scale $[10,16]$.

Much of the information available for dung beetles, an insect group recognized as ecological indicators of human disturbance [20], has come from studies at the community level, and information at the population level is limited to a few species [21,22]. Currently, most published population studies about dung beetles have been carried out in relatively small areas over short periods of time ( $<8$ months) covering a single climatic season, mainly the rainy season [23-25], limiting our comprehension of the population ecology of this group of insects. It is useful to understand the ecological processes that operate at a population level for evaluating species-specific responses to environmental changes and for identifying the life-history traits associated with extinction risk [26-28].

The objective of the present study was to evaluate changes in the abundance and population structure of two dung beetles with differing natural history traits, Deltochilum mexicanum (Burmeister, 1848) and Dichotomius satanas (Harold, 1867), over 12 months in a human-modified landscape. Both species are typical of Mexican cloud forest, which is considered a conservation priority because it shelters a high diversity and a high number of endemic species [29]. Both beetle species are large in size (>10 mm), which facilitates their marking, and are relatively abundant throughout the year [30,31]. Specifically, D. mexicanum is a copronecrophagous and nocturnal roller species, generally associated with well-preserved forested areas [32,33]. Meanwhile, D. satanas is a coprophagus and nocturnal tunneler species mostly found in open and semi-open areas altered by human activities (e.g., secondary forests, orchard crops, and pastures) [30,31,34]. Using mark-recapture data, we aimed to answer the following questions: (1) How does the abundance of D. mexicanum and D. satanas vary throughout the year in two types of vegetation cover (forested and non-forested) in a human-modified landscape? (2) How does the population structure of D. mexicanum and D. satanas vary throughout the year in regard to their age and sex ratios? And, finally, (3) how do the estimates of population size, survival rate, and the number of new individuals for D. mexicanum and D. satanas change over one year at the landscape scale? 


\section{Material and Methods}

\subsection{Study Area}

The study was carried out on the eastern slope of Cofre de Perote to the west of the city of Xalapa, Veracruz, Mexico. The climate is temperate and humid year-round. The average annual precipitation varies between 1500 and $2000 \mathrm{~mm}$ and the average temperature between 19 and $17^{\circ} \mathrm{C}$ [35]. Three seasons can be distinguished: A cold and dry season from November to March ( $X^{\circ} \mathrm{SD}$ : $16 \pm 1.7^{\circ} \mathrm{C}$, precipitation: $\left.283 \mathrm{~mm}\right)$, a warm and dry season from April to May $\left(21 \pm 0.6{ }^{\circ} \mathrm{C}, 173 \mathrm{~mm}\right)$, and a rainy season from June to October $\left(19.4 \pm 0.7^{\circ} \mathrm{C} ; 1131 \mathrm{~mm}\right)$ [36]. The vegetation type of this region corresponds with cloud forest [37].

The sampling was performed in a landscape of 126 ha $\left(1.26 \times 1.16 \mathrm{~km}\right.$; $19^{\circ} 30^{\prime} 55.81^{\prime \prime} \mathrm{N}$, $97^{\circ} 0^{\prime} 19.88^{\prime \prime} \mathrm{W}$ ) with an elevation range of 1520 to 1780 masl (Figure 1 ). The landscape is composed of well-preserved cloud forest (50\%), secondary vegetation $(23.5 \%)$, pastures $(24 \%$, with and without trees), and commercial tree plantations (2.5\%). In the present study, the vegetation covers were categorized into two types: Forested areas (F) or non-forested areas (NF, including land uses associated with human activities). This landscape exemplifies the current state of the Mexican cloud forest, which mostly exists within a mosaic of different land uses as a result of agricultural expansion and urban growth. Only $1 \%$ of the original distribution of cloud forest remains [36].

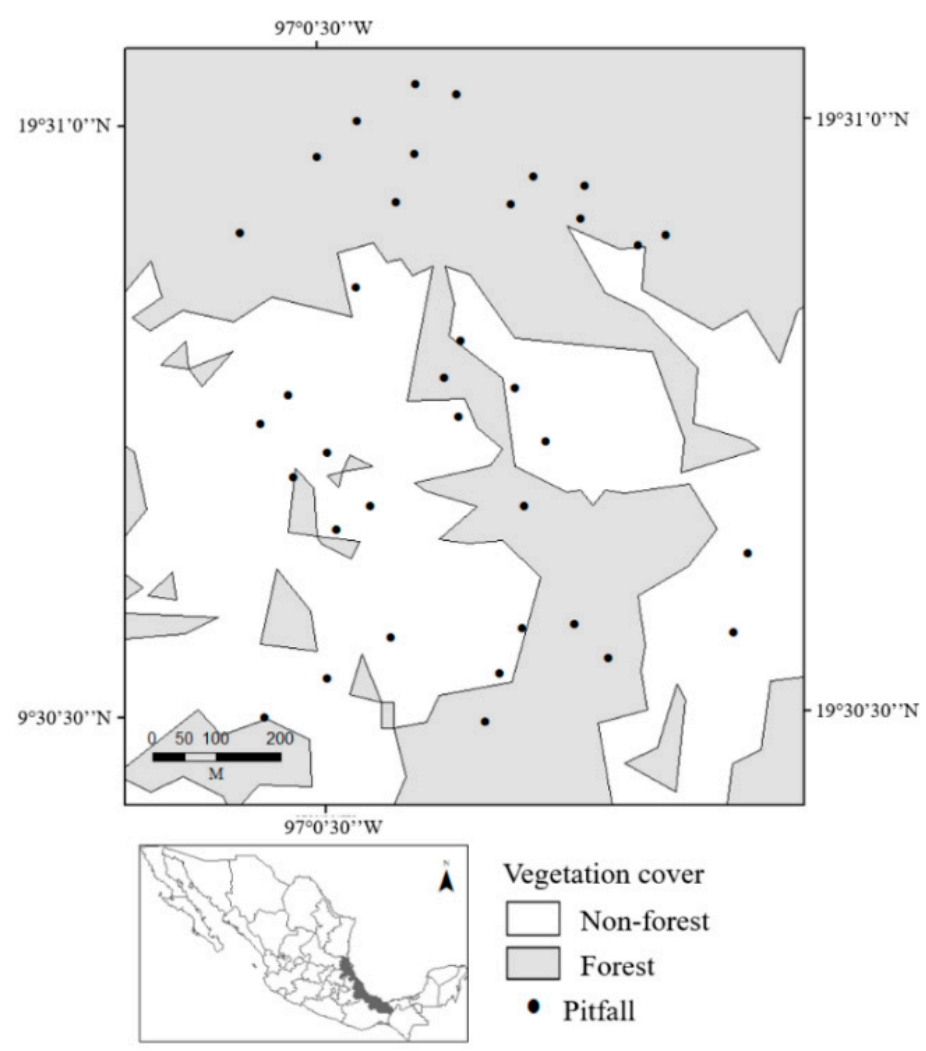

Figure 1. Spatial distribution of the pitfall traps used to sample populations of Deltochilum mexicanum and Dichotomius satanas over one year (August 2015 to July 2016) in a human-modified cloud forest landscape in Veracruz, Mexico.

\subsection{Mark-Recapture of Dung Beetles}

The mark-recapture of dung beetles was carried out between August 2015 and July 2016. In total, 36 non-lethal pitfall traps were used: 16 traps were placed in forested areas and 20 in non-forested areas. All traps were separated by a distance of at least $50 \mathrm{~m}$ (Figure 1). Each trap consisted of a 1L disposable plastic container buried at the ground level with a plastic funnel secured in the upper portion to 
prevent beetles from escaping [38]. Traps baited with $45 \mathrm{~g}$ of human excrement were placed for $24 \mathrm{~h}$ capture periods, leaving a day between sampling events to guarantee the free dispersion of the marked individuals. This resulted in five effective sampling days $(120 \mathrm{~h}$ in total $)$ per month. The individuals captured in each event were marked with a consecutive number that was scratched on the surface of the pronotum or elytron with a Mototool (Dremel Stylus $1100^{\circledR}$, Dremel, Mexico) following the protocol of Martínez-Quintero et al. [39]. At the end of each $24 \mathrm{~h}$ period, marked individuals were released next to the trap of capture. The sex of each individual was determined, and the dates of mark-recapture, trap location, and cover type (F or NF) where each individual was captured and recaptured were recorded. The relative age of each individual (two categories: Teneral or recently emerged and non-teneral adult individuals) was also determined based on the degree of sclerotization of the exoskeleton, which is soft, flexible, and pale in color in recently emerged individuals [40].

\subsection{Environmental Variables}

Temperature and humidity were measured in the study area with six data loggers (iButton ${ }^{\circledR}$, Maxim Integrate, San Jose, CA, USA). Three were installed in forested sites and three in non-forested sites, covering most of the landscape. The data loggers were programmed to record the variables every $10 \mathrm{~min}$ and remained in the field throughout the entire sampling period except during the month of August 2015. Additionally, accumulated monthly precipitation was obtained from the closest meteorological station located $\sim 3.4 \mathrm{~km}$ from the study area. These data are available on the National Online Portal for Transparency (Portal Nacional de Transparencia) of the National Institute for Transparency, Access to Information, and Personal Data Protection (Instituto Nacional de Transparencia, Acceso a la Información y Protección a Datos Personales).

\subsection{Data Analysis}

\subsubsection{Annual Variation in Abundance and Environmental Variables}

To examine variation in the abundance of the two species throughout the year, population curves were constructed [1] for the landscape and for each cover type (F and NF). At the landscape level, observed abundance was expressed in two ways: (1) As the total number of individuals captured per month, or total abundance $\left(\mathrm{N}_{\text {total }}\right)$, and (2) as the net number of individuals, or net abundance $\left(\mathrm{N}_{\text {net }}=\right.$ $\mathrm{N}_{\text {total }}-$ number of individuals recaptured per month). For cover type, the curves were constructed considering only net abundance $\left(\mathrm{N}_{\text {net }}\right)$. The behavior of these curves in addition to available knowledge on the natural history of each species provides information on the structure and temporal variation of populations, including voltinism type, breeding cycle duration, and oviposition periods [1].

To establish whether the temporal variation in the abundance of each species was related to cover type (F and NF), generalized linear models (GLMs) were fit to the data. $\mathrm{N}_{\text {net }}$ was modeled with respect to month and cover type (fixed factors). Besides the null model, four models were specified per species, three with respect to (i) month; (ii) cover type; (iii) month + cover type, and (iv) a complete model including the interaction between month and cover type. For the model fit, a negative binomial distribution was used $(\mathrm{g}(\mathrm{x})=1 / \mathrm{x})$, which allows overdispersion to be reduced in cases where count response variables are associated with a high frequency of zeros [41,42]. The selection of the most suitable model was based on the significance of the model, the AICc values (second-order Akaike information criterion for small samples <40) [43], the normality of the residuals (Shapiro test, $\alpha=0.05$ ), and the overdispersion coefficient $(\hat{\mathrm{c}}<1.5)$ [41]. In addition, the relationship between $\mathrm{N}_{\text {net }}$ and monthly accumulated precipitation, temperature, and humidity was evaluated. For each variable, a simple linear regression was fit to the data, and the fit of each model was then evaluated based on the normality of the residuals. All models were fit using R code [44]. 


\subsubsection{Population Structure}

The age ratio (AR) was calculated as the number of non-teneral individuals/number of teneral individuals. The adult sex ratio (ASR) was calculated considering only non-teneral adults as follows: Male/male + female. The resulting value of the ASR is 0.5 if the number of males and females is equal [45]. This method is the most recommended for estimating sex ratios in nature given that it considers individuals as discrete units and thereby reflects the relative abundance of each sex in a population [46]. As the expected ASR is $0.5(1: 1)$, we used chi-square $\left(\chi^{2}\right)$ tests to determine if the observed ASR statistically differed from the expected ratio.

Using the Cormack-Jolly-Seber (CJS) method [47,48], three population parameters were estimated per mark-recapture event for each species: Population size $(\hat{N} i)$, survival rate $(\hat{\Phi} i)$, and the number of new individuals or recruitment rate (birth + immigration) $(\hat{B} i)$. Since it is not possible to predict or establish the trends of population parameters beyond the evaluated year using the CJS method, the results and discussion are focused on the maximum and minimum values of the estimations, highlighting the possible causes of variation in these values. The CJS method is appropriate for estimating parameters in open populations and does not overestimate the amplitude of the confidence intervals [49]. The population parameters were estimated by FSA package 0.4 .3 using R code $[44,50]$.

\section{Results}

During the sampling year, 66 mark-recapture events were carried out in which 1960 individuals were marked (1260 D. mexicanum and 700 D. satanas). Considering both species, the net recapture rate (i.e., single recapture) was $11 \%$ (214 individuals). Deltochilum mexicanum presented almost three times more single recaptures $(14 \%, 176$ individuals) than $D$. satanas $(5 \%, 38$ individuals). With respect to multiple recaptures, 22 individuals of $D$. mexicanum were recaptured two times, and five were recaptured three times. Only two individuals of $D$. satanas were recaptured two times. For both species, the minimum time interval between capture and recapture was $48 \mathrm{~h}$, and the maximum interval was 365 days for D. mexicanum and 306 days for $D$. satanas.

\subsection{Annual Variation in Abundance and Environmental Variables}

The seasonal variation in the abundance pattern of abundance was similar for both species. The abundance curves presented a peak between the end of summer (August) and the beginning of autumn (September) followed by a reduction in captures until the end of winter (February) when no individuals were captured. In the following months, a slight increase in the number of individuals of both species was observed and maintained with some fluctuations until the beginning of summer (June 2016) (Figure 2A,B).

Deltochilum mexicanum was more abundant in forested areas (888 individuals, $70 \%$ ) than in non-forested areas (372 individuals, $30 \%$ ), whereas $D$. satanas presented the opposite pattern (forest: 181 individuals, $26 \%$; non-forest: 519 individuals, $74 \%$ ). In forested areas, the D. mexicanum population presented two peaks in abundance: One during the transition from summer to autumn (between August and September) and another of smaller magnitude near the end of spring (May) (Figure 2C). The abundance of $D$. satanas in forested areas was relatively low ( $\leq 50$ individuals/month) yet constant throughout the year (Figure 2C). In non-forested areas, both species followed a similar pattern: The number of individuals rapidly decreased toward the end of the year but increased once again toward the end of winter (March) (Figure 2D). 

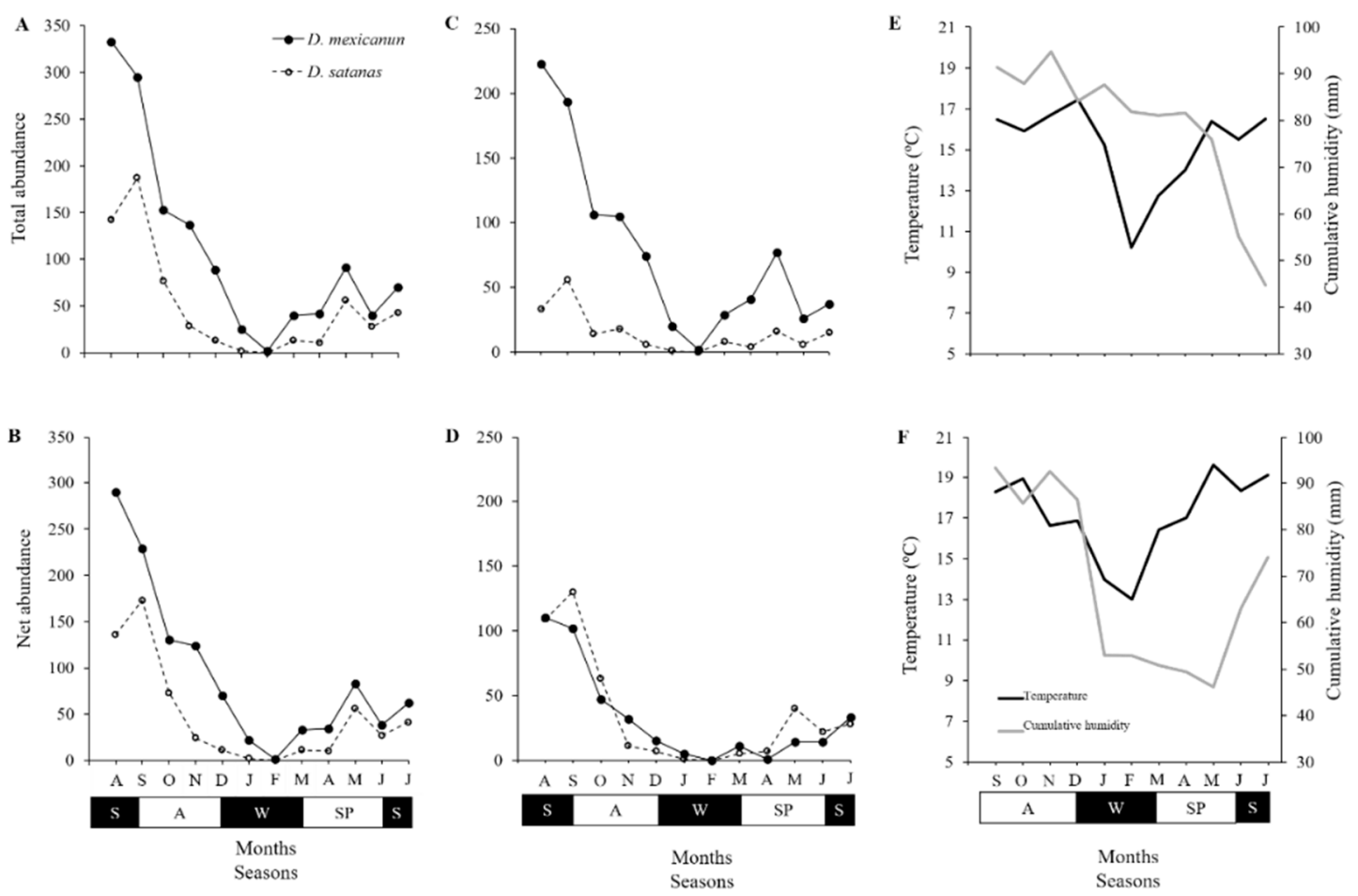

Figure 2. Population curves of Deltochilum mexicanum and Dichotomius satanas in a human-modified cloud forest landscape in Veracruz, Mexico. (A) Population curves of total abundance $\left(\mathrm{N}_{\text {total }}\right.$ : Total number of individuals captured per month) and (B) net abundance $\left(\mathrm{N}_{\text {net }}\right.$ : Total number of individuals captured per month - number of individuals recaptured per month). In addition, species populations curves considering the type of vegetation cover, forested (C) or non-forested (D); and the annual variation in temperature $\left({ }^{\circ} \mathrm{C}\right)$ and cumulative humidity $(\mathrm{mm})$ in forested areas $(\mathbf{E})$ and non-forested areas $(\mathbf{F})$ are shown. Seasons: $\mathrm{S}=$ summer, $\mathrm{A}=$ autumn, $\mathrm{W}=$ winter, and $\mathrm{SP}=$ spring.

At the landscape level, the $\mathrm{N}_{\text {net }}$ of both species differed with respect to month and type of vegetation cover, and the interaction between these latter two factors was not significant (Figure S1, Table S1). The $\mathrm{N}_{\text {net }}$ of $D$. mexicanum was linearly and positively related with precipitation at the landscape scale $\left(R^{2}=0.19 ; P=0.026\right)$, with temperature in the forested areas $\left(R^{2}=0.30 ; P=0.052\right)$, and with humidity in the non-forested areas $\left(\mathrm{R}^{2}=0.50 ; P=0.009\right)$ (Table S1). The net abundance of $D$. satanas was not related to any of the variables in either type of vegetation covers (Table S1).

\subsection{Population Structure}

For the populations of both species, the frequency of teneral individuals was low, representing $13 \%$ and $8 \%$ of the D. mexicanum $(\mathrm{AR}=6.67)$ and $D$. satanas $(\mathrm{AR}=11.10)$, respectively. This pattern was maintained throughout the year (Figure 3A,C). The largest number of teneral individuals of both species was found during the transition between summer and autumn (between August and September) (Figure 3A,C). 

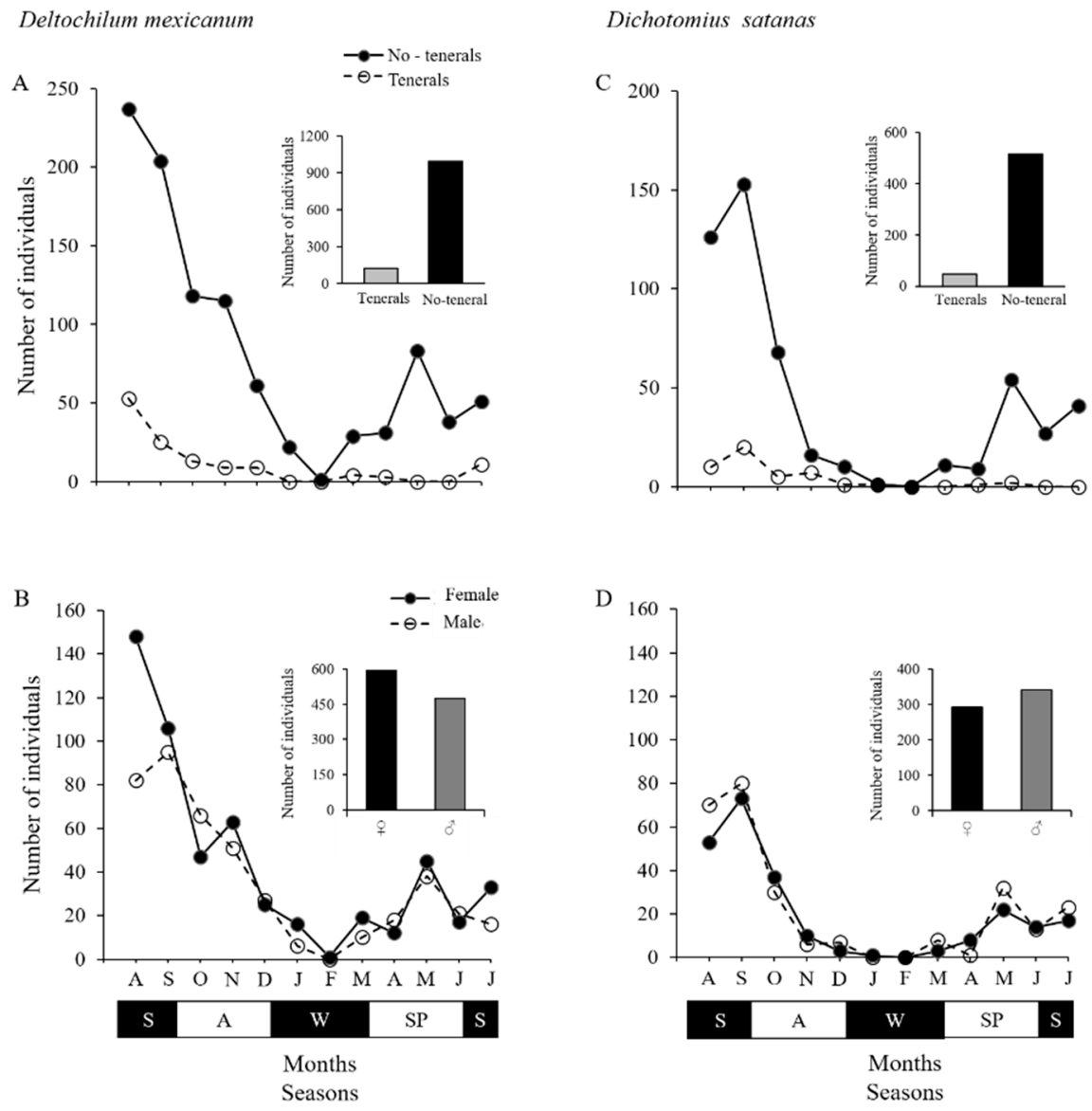

Figure 3. Annual variation in the number of teneral and non-teneral individuals $(\mathbf{A}, \mathbf{C})$ and in the number of males and females in Deltochilum mexicanum and Dichotomius satanas populations (B,D) in a human-modified cloud forest landscape in Veracruz, Mexico. Seasons: $\mathrm{S}=$ summer, $\mathrm{A}=$ autumn, $\mathrm{W}=$ winter, and $\mathrm{SP}=$ spring.

The ASR of D. mexicanum was significantly female-biased ( $\sigma^{7} 475$ and $\$ 594$, ASR $=0.44 ; \chi^{2}=13.2$; $P<0.05$, Figure 3B). However, in the months of October, April, and June, the number of males surpassed the number of females (Figure 3B). The ASR of D. satanas was male-biased ( $0^{\top} 342$ and $\$ 293$, ASR $=0.53 ; \chi^{2}=3.7 ; P=0.05 ;$ Figure $3 \mathrm{D}$ ). Males were more numerous than females toward the end of the year and in the months of March, May, and July (Figure 3D).

The maximum estimated population size $(\hat{N} i)$ was similar between species $(D$. mexicanum $=$ 4687 individuals and $D$. satanas $=4395$ individuals). The estimated number of new individuals and the rate of survival were higher for $D$. mexicanum $(\hat{B} i=2.6 ; \hat{\phi} i=6.48)$ than for $D$. satanas $(\hat{B} i=1.2 ; \hat{\phi} i=5.44)$. For both species, the estimates for the three parameters varied considerably over the course of the 66 mark-recapture events; the highest values were recorded in autumn and the lowest values in winter (Figure 4). 
Deltochilum mexicanum
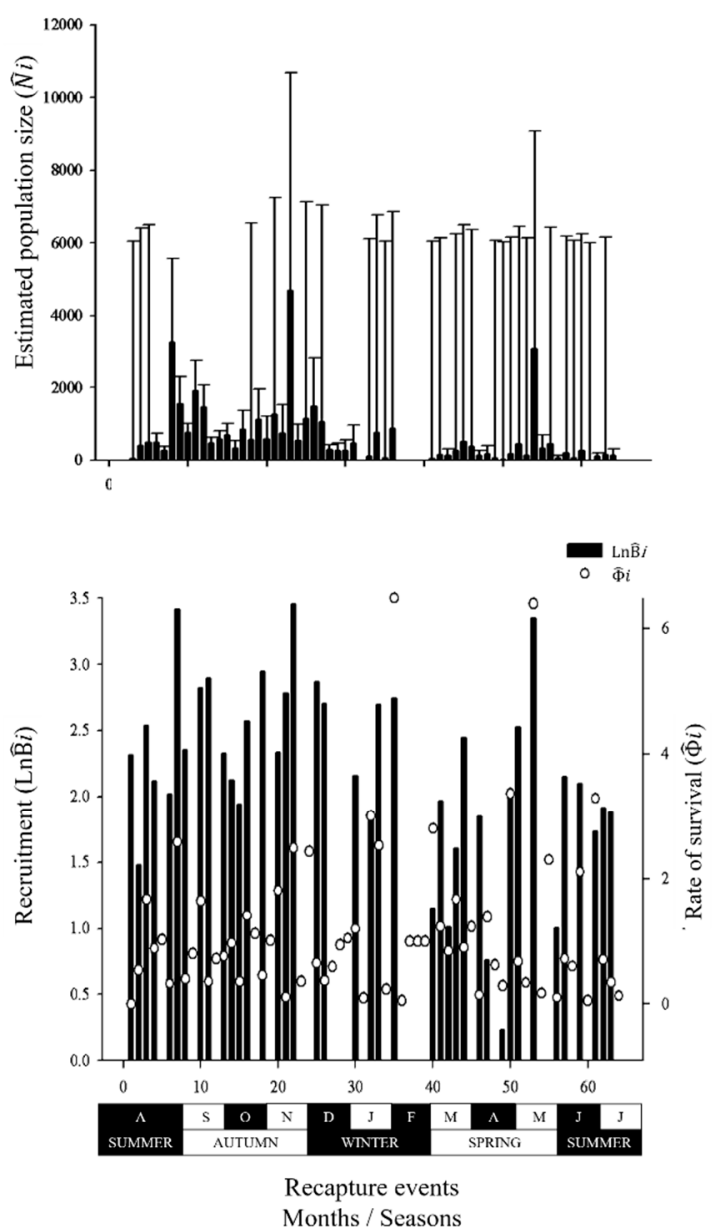

Dichotomius satanas
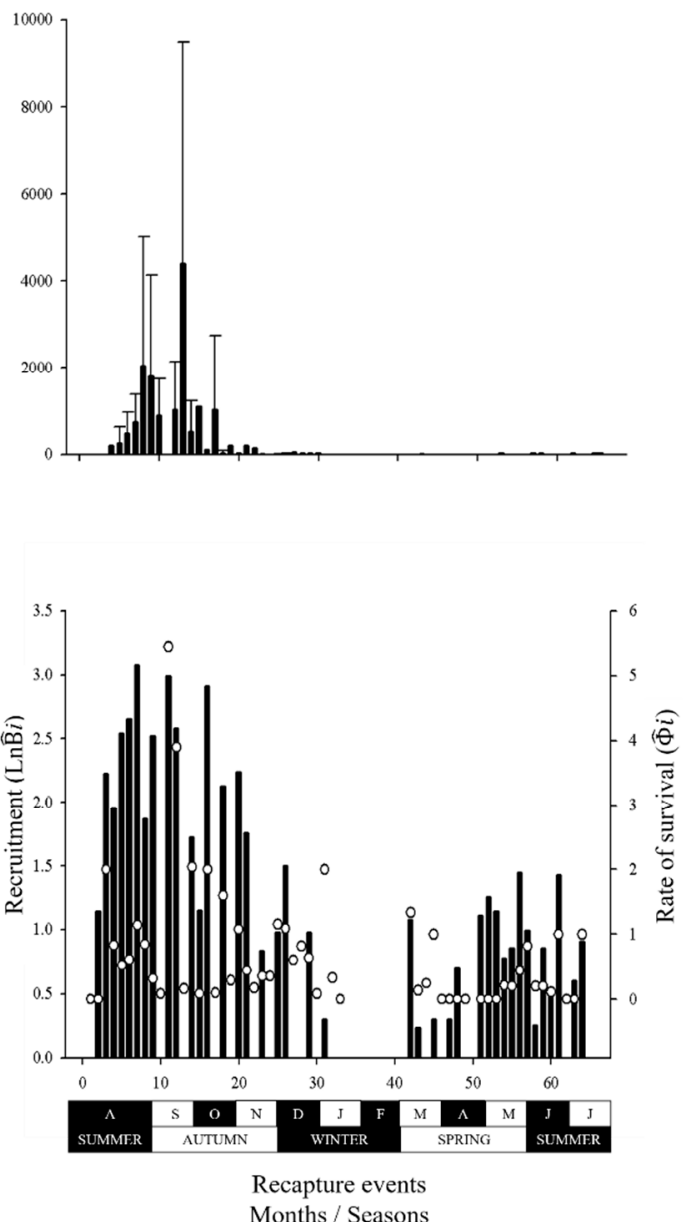

Figure 4. Estimated population size $(\hat{N} i \pm 95 \% \mathrm{CI})$, recruitment $(\hat{B} i$, (birth + immigration $) \pm 95 \% \mathrm{CI})$, and rate of survival $(\hat{\Phi} i)$ estimated for Deltochilum mexicanum and Dichotomius satanas populations based on 66 mark-recapture events over one year (August 2015-July 2016) in a human-modified cloud forest landscape in Veracruz, Mexico. Recruitment $(\hat{B} i)$ was transformed by $\ln (\operatorname{Ln} \hat{B} i)$ to facilitate comparison

\section{Discussion}

Our study represents an initial effort to understand seasonal variation in the population structure of two dung beetles, D. mexicanum and D. satanas, in a human-modified landscape in the cloud forest region of Mexico, one of the most threatened ecosystems in the country. For both species, high recapture rates ( $5 \%$ and $14 \%$ ) were achieved [21], and it was possible to describe changes in abundance and breeding patterns and to estimate the demographic parameters, such as population size, survival rate, and recruitment rate. Our results are of great value considering that, recently, dung beetles were included on the Red List of Threatened Species by the International Union for Conservation of Nature (http:/ / www.iucnredlist.org). Currently, for 80 percent of the species in this list, information on the status and tendency of populations is unknown.

The annual abundance patterns of D. mexicanum and D. satanas were characterized by a maximum between the end of summer and beginning of autumn followed by a strong reduction in the number of individuals during winter. This suggests that both species have a univoltine reproductive behavior and a short breeding season that is restricted to the warm and rainy season [1]. According to Hanski and Cambefort [51], the adult feeding behavior required to reach sexual maturity and the search for mates also occur during seasons with optimal environmental conditions. Several studies suggest that the life cycle of dung beetles, especially the nesting and emergence of new individuals (tenerals) is primarily 
modulated by temperature and precipitation as well as the availability of food [40,52,53]. Our results and those observed in the tropical dry forest $[54,55]$ suggest that the activity of dung beetles decreases considerably during the most climatically severe seasons of the year, such as during the dry season or when temperatures are low. During these periods, beetles probably enter into states of physiological inactivity below ground [56,57] and, therefore, the detection of individuals decreases considerably. For this reason, studies on the population dynamics and structure that document temporal variation in abundance over long periods ( $>1$ year) are necessary to understand the effects of climate variation and the modification of habitats in both the medium and long term.

The results also suggest that the type of vegetation cover is a key factor that explains the distribution of species at the landscape level. We confirmed, similar to several previous studies at the community level, that D. mexicanum prefers well-conserved cloud forest areas [32,33], whereas D. satanas prefers modified environments, including secondary vegetation, coffee plantations, and pastures [30,31,34]. The preference of dung beetle species for a determined type of environment is essentially a response to microclimatic variables, which are driven by structural vegetation characteristics [58] and the composition and configuration of the landscape [32,59,60]. However, several Scarabaeinae species have a high dispersion capacity ( $\sim 2 \mathrm{~km}$ in $48 \mathrm{~h}$ ) and can use extensive portions of the landscape [25,61]. For this reason, population studies that consider more extensive landscapes are necessary to identify how environmental attributes affect the spatial-temporal dynamics and persistence of populations.

Although much of our knowledge on the reproductive biology of Scarabaeinae comes from laboratory studies, our results coincide with the known reproductive biology of several species belonging to the genera Deltochilum and Dichotomius [40,56]. The maximum recorded number of individuals and the presence of a single peak of the emergence of tenerals per year suggest that $D$. mexicanum and D. satanas have a larval development phase of approximately 12 months given that the period between oviposition and emergence of new individuals corresponds with that of larval development. This has also been reported for other species of dung beetles with similar life-history traits (i.e., univoltine, large in size, and inhabit seasonal environments) [57,62-64]. From these results, we can also infer that both species have lifetimes equal to or greater than 12 months. Previous records for 24 dung beetle species under laboratory conditions indicate that adult longevity varies from 1.5 to 24 months $[65,66]$. Such reproductive biological characteristics correspond with those of $K$-strategist species, a trait considered typical of dung beetles, which prioritize reproductive efficiency to guarantee the survival of offspring [40].

An ASR biased toward one of the sexes suggests that environmental conditions differentially affect males and females $[67,68]$. Differential mortality is common in species like dung beetles in which the sexes have distinct nutritional requirements and energy expenditures as a result of differential mobility and investment in parental care [68]. In these cases, the ASR may be biased toward the sex with lesser probability of death [69-71]. Although we do not know with certainty which factors determined the sexual proportions of the studied species, an ASR biased towards the females, as observed for D. mexicanum, is a characteristic of populations that present a high level of spatial aggregation where males do not compete for the females [72]. Meanwhile, an ASR biased toward males, as observed for D. satanas, has been linked to increased intrasexual competition for resources and couples, which could lead to a highly segregated population in space [73].

With respect to the maximum estimated population size, both species presented a similar population density at the landscape level (D. mexicanum: 37 individuals/ha; D. satanas: 35 individuals/ha). This suggests that $D$. mexicanum and $D$. satanas have similar reproductive potential. The maximum estimated population size for both populations is high ( $\geq 1000$ individuals) and guarantees the persistence of both populations in the landscape in the long term [2]. Our results agree with other population studies on dung beetles carried out in modified Neotropical landscapes in which estimated population sizes varied between 5000 and 25,000 individuals [25,74,75]. 
The comparison of the maximum estimates for new individuals and the survival rate enables us to assume that the processes of entry and exit of individuals distinctly contribute to the population dynamics of each species. For example, D. satanas has a greater capacity of movement in the landscape, including movement through modified areas [76], thus the migration of individuals appears to strongly contribute toward the population dynamics of this species. Meanwhile, D. mexicanum is restricted to forested areas with lower capacity to movement [76], thus the probability of finding mates during the reproductive season could be greater, which results in a high entry of new individuals in the population via birth. However, to confirm these hypotheses, more detailed demographic studies are necessary at larger spatial and temporal scales.

In conservation biology, populations are the unit of primary interest, and understanding the structure and dynamics of insect populations helps to establish the bases for practical conservation measures at the species level [77]. Our results contribute to establishing the conservation status of two dung beetles based on two biological parameters of interest for conservation: Changes in abundance over time and population size [77]. The D. mexicanum population could be more vulnerable to habitat loss than $D$. satanas because of its close association with forest areas and lower mobility in the landscape. Such information could be useful for functional connectivity models in order to identify critical elements of the landscape for the management and conservation of cloud forest species. Nonetheless, population studies at the landscape scale are necessary to identify the long-term responses of dung beetles to habitat modification and climate change.

Information is lacking on many aspects of the population ecology of dung beetles in tropical regions. Although the abundance of both dung beetle species in this study clearly fluctuated with seasonal changes, to understand the magnitude of these changes based on the recommendations of Hanski [78], future studies on the population ecology of dung beetles should (i) implement monthly sampling for at least three years; (ii) perform long-term sampling over extensive geographical areas (>100 ha); (iii) take into account innovations in mark-recapture methods for medium- and small-sized species $(<10 \mathrm{~mm}$ ); (iv) aim to explain the specific responses of different species at the population level to environmental changes resulting from the modification of ecosystems and climate, and $(\mathrm{v})$ simultaneously evaluate temporal variation in the population structure and the reproductive phenology of dung beetles.

\section{Conclusions}

Our results demonstrated that the population structure and dynamics of the studied dung beetle are modulated at the local scale by environmental conditions, and are associated with seasonal variation. Differences in the life-history traits of species, including habitat preferences, reproductive behavior, food relocation behavior, nesting behavior, and the capacity for movement, appear to play an important role in the population structure and in demographic processes (i.e., mortality, migration, and birth) that are determinant of population dynamics.

Supplementary Materials: The following are available online at http://www.mdpi.com/2075-4450/10/1/2/s1. Figure S1: Temporal variation in the mean number of individuals $( \pm 95 \% \mathrm{CI})$ of Deltochilum mexicanum and Dichotomius satanas populations considering the type of vegetation cover (forest or no-forest) in a human-modified cloud forest landscape in Veracruz, Mexico. Seasons: $\mathrm{S}=$ summer, $\mathrm{A}=$ autumn, $\mathrm{W}=$ winter, and $\mathrm{SP}=\mathrm{spring}$; Table S1: Generalized linear models (GLM) with a negative binomial distribution and simple linear models (Lm) for evaluating the relationship between the net abundance $\left(\mathrm{N}_{\mathrm{Net}}\right)$ of Deltochilum mexicanum and Dichotomius satanas and environmental variables at a landscape level, and type of vegetation cover (forested or non-forested) in a human-modified cloud forest landscape in Veracruz, Mexico. Significant or selected models in bold. $\mathrm{N}_{\mathrm{Net}}=$ net abundance of species. Cover = cover type (forested or non-forested). Mon = months of sampling. $\mathrm{AP}=$ accumulated monthly precipitation $(\mathrm{mm}) . \mathrm{T}=$ monthly temperature $\left(\mathrm{T}^{\circ} \mathrm{C}\right) . \mathrm{H}=$ monthly relative humidity (\% RH).

Author Contributions: Conceptualization, J.W.B., C.A.C.-M. and F.E.; formal analysis, J.W.B. and C.A.C.-M.; methodology, C.A.C.-M. and F.E.; resources, F.E.; writing-original draft, J.W.B.; writing-review and editing, J.W.B., C.A.C.-M. and F.E. 
Funding: Financial support and a Ph.D. scholarship (No. 589280) were received for this research from the Mexican National Council for Science and Technology (CONACYT). Mexican Agency for International Development Cooperation (AMEXID) and Pacific Alliance funding part of conceptualization and field work (Cod. 3101416).

Acknowledgments: We thank Ricardo Madrigal Chavero, and biologist Jaime Pelayo for their support with the field work. We appreciate the comments of the evaluators, they helped to improve the document.

Conflicts of Interest: The authors declare no conflict of interest. The funding sponsors had no role in the design of the study; in the collection, analysis, or interpretation of data; in the writing of the manuscript; or in the decision to publish the results.

\section{References}

1. Clark, L.R.; Geier, P.W.; Hugues, R.D.; Morris, R.F. The Ecology of Insect Populations in Theory and Practice, 4th ed.; The English Language Book Society and Methuen Book Society: London, UK, 1978; pp. 1-24, ISBN 416766900.

2. Pulliam, H.R.; Dunning, J.B. Demographic Processes: Population dynamics on Heterogeneous Landscape. In Principles of Conservation Biology, 1st ed.; Meffe, G.K., Carroll, C.R., Eds.; Sinauer Associates, Inc.: Sunderland, MA, USA, 1994; pp. 180-182, ISBN 0878935195.

3. Williams, B.K.; Nichols, J.D.; Conroy, M.J. Analysis and Management of Animal Populations, 1st ed.; Academic Press: San Diego, CA, USA, 2002; pp. 3-9, ISBN 0127544062.

4. Roy, D.B.; Rothery, P.; Moss, D.; Pollard, E.; Thomas, J.A. Butterfly numbers and weather: Predicting historical trends in abundance and the future effects of climate change. J. Anim. Ecol. 2001, 70, 201-217. [CrossRef]

5. Daszak, P.; Cunningham, A.A.; Hyatt, A.D. Infectious disease and amphibian population declines. Divers. Distrib. 2003, 9, 141-150. [CrossRef]

6. Lemoine, N.; Bauer, H.G.; Peintinger, M.; Bohning-Gaese, K. Effects of climate and land-use change on species abundance in a central European bird community. Conserv. Biol. 2007, 21, 495-503. [CrossRef] [PubMed]

7. Wolda, H. Insect seasonality: Why? Annu. Rev. Ecol. Syst. 1988, 19, 1-18. [CrossRef]

8. Kishimoto-Yamada, K.; Itioka, T. How much have we learned about seasonality in tropical insect abundance since Wolda (1988)? Entomol. Sci. 2015, 18, 407-419. [CrossRef]

9. Gill, H.K.; Goyal, G.; Chahil, G. Insect Diapause: A Review. J. Agric. Sci. Technol. 2017, 7, 454-473. [CrossRef]

10. Birch, L.C. The intrinsic rate of natural increase of an insect population. J. Anim. Ecol. 1948, 17, 15-26. [CrossRef]

11. Varley, G.C.; Gradwell, G.R.; Hassell, M.P. Insect Population Ecology: An Analytical Approach, 1st ed.; University of California Press: Oakland, CA, USA, 1973; pp. 75-93, ISBN 0520026675.

12. Rebaudo, F.; Rabhi, V.-B. Modeling temperature-dependent development rate and phenology in insects: Review of major developments, challenges, and future directions. Entomol. Exp. Appl. 2018, 166, 607-617. [CrossRef]

13. Pianka, E.R. Latitudinal gradients in species diversity: A review of concepts. Am. Nat. 1966, 910, 33-46. [CrossRef]

14. Scalco, V.W.; De Morais, A.B.B.; Romanowski, H.P.; Mega, N.O. Population dynamics of the swallowtail butterfly Battus polystictus polystictus (Butler) (Lepidoptera: Papilionidae) with notes on its natural history. Neotrop. Entomol. 2016, 45, 33-43. [CrossRef]

15. Young, A.M. Population Biology of Tropical Insects, 1st ed.; Plenum Press: New York, NY, USA, 1982; pp. 273-333, ISBN 0306408430.

16. Danks, H.V. The elements of seasonal adaptations in insects. Can. Entomol. 2007, 139, 1-44. [CrossRef]

17. Gurevitch, J.; Fox, G.A.; Fowler, N.L.; Graham, C.H. Landscape demography: Population change and its drivers across spatial scales. Q. Rev. Biol. 2016, 91, 459-485. [CrossRef] [PubMed]

18. Fred, M.S.; O'Hara, R.B.; Brommer, J.E. Consequences of the spatial configuration of resources for the distribution and dynamics of the endangered Parnassius apollo butterfly. Biol. Cons. 2006, 130, 183-192. [CrossRef]

19. Hodgson, J.A.; Thomas, C.D.; Oliver, T.H.; Anderson, B.J.; Brereton, T.M.; Crone, E.E. Predicting insect phenology across space and time. Glob. Chang. Biol. 2011, 17, 1289-1300. [CrossRef] 
20. Nichols, E.S.; Gardner, T.A. Dung beetles as a candidate study taxon in applied biodiversity conservation research. In Ecology and Evolution of Dung Beetles, 1st ed.; Simmons, L.W., Ridsdill-Smith, T.J., Eds.; Blackwell Publishing Ltd.: Chichester, UK, 2011; pp. 267-290, ISBN 9781444333152.

21. Barretto, J.W.; Cultid-Medina, C.A.; Escobar, F. Population Ecology of Dung Beetle (Scarabaeinae): A Review. unpublished.

22. Roslin, L.W.; Viljanen, T.J. Dung beetle populations: Structure and consequences. In Ecology and Evolution of Dung Beetles, 1st ed.; Simmons, L.W., Ridsdill-Smith, T.J., Eds.; Blackwell Publishing Ltd.: Chichester, UK, 2011; pp. 267-290, ISBN 9781444333154112.

23. Peck, S.B.; Forsyth, A. Composition, structure, and competitive behaviour in a guild of Ecuadorian rain forest dung beetles (Coleoptera; Scarabaeidae). Can. J. Zool. 1982, 60, 1624-1634. [CrossRef]

24. Roslin, T.; Avomaa, T.; Leonard, M.; Luoto, M.; Ovaskainen, O. Some like it hot: Microclimatic variation affects the abundance and movements of a critically endangered dung beetle. Insect Conserv. Divers. 2009, 2, 232-241. [CrossRef]

25. Cultid-Medina, C.A.; Martínez-Quintero, B.G.; Escobar, F.; de Ulloa, P.C. Movement and population size of two dung beetle species in an Andean agricultural landscape dominated by sun-grown coffee. J. Insect Conserv. 2015, 19, 617-626. [CrossRef]

26. Carey, J.R. Applied Demography for Biologists: With Special Emphasis on Insects, 1st ed.; Oxford University Press: New York, NY, USA, 1993; pp. 140-180, ISBN 0195066871.

27. Sutherland, W.J. From Individual Behavior to Population Ecology, 1st ed.; Oxford University Press: Oxford, UK, 1996; pp. 103-116, ISBN 0198549113.

28. Forrest, J.; Miller-Rushing, A.J. Toward a synthetic understanding of the role of phenology in ecology and evolution. Philos. Trans. R. Soc. Lond. B Biol. Sci. 2010, 365, 3101-3112. [CrossRef]

29. CONABIO. El Bosque Mesófilo de Montaña en México: Amenazas y Oportunidades para su Conservación y Manejo Sostenible; Comisión Nacional para el Conocimiento y Uso de la Biodiversidad: Tlalpan, Distrito Federal, Mexico, 2010.

30. Pineda, E.; Moreno, C.; Escobar, F.; Halffter, G. Frog, bat, and dung beetle diversity in the cloud forest and coffee agroecosystems of Veracruz, Mexico. Conserv. Biol. 2005, 19, 400-410. [CrossRef]

31. Halffter, G.; Pineda, E.; Arellano, L.; Escobar, F. Instability of copronecrophagous beetle assemblages (Coleoptera: Scarabaeinae) in a mountainous tropical landscape of Mexico. Environ. Entomol. 2007, 36, 1397-1407. [CrossRef]

32. Rös, M.; Escobar, F.; Halffter, G. How dung beetles respond to a human modified variegated landscape in Mexican cloud forest: A study of biodiversity integrating ecological and biogeographical perspectives. Divers. Distrib. 2012, 18, 377-389. [CrossRef]

33. Alvarado, F.; Escobar, F.; Montero-Muñoz, J. Diversity and biogeographical makeup of the dung beetle communities inhabiting two mountains in the Mexican Transition Zone. Org. Divers. Evol. 2014, 14, 105-114. [CrossRef]

34. Arellano, L.; Favila, M.E.; Huerta, C. Diversity of dung and carrion beetles in Mexican fragmented tropical montane cloud forests and shade coffee plantations. Biodivers. Conserv. 2005, 14, 601-615. [CrossRef]

35. Williams-Linera, G.; Vizcaíno-Bravo, Q. Cloud forests on rock outcrop and volcanic soil differ in indicator tree species in Veracruz, Mexico. Rev. Mex. Biodivers. 2016, 87, 1265-1274. [CrossRef]

36. Williams-Linera, G. Tree species richness complementarity, disturbance y fragmentation in a Mexican tropical montane cloud forest. Biodivers. Conserv. 2002, 11, 1825-1843. [CrossRef]

37. Williams-Linera, G.; Toledo-Garibaldi, M.; Gallardo, H.C. How heterogeneous are the cloud forest communities in the mountains of central Veracruz, Mexico. Plant Ecol. 2013, 214, 685-701. [CrossRef]

38. Cultid-Medina, C.A.; Medina, C.A.; Martínez, B.; Escobar, A.F.; Constantino, L.M.; Betancur, N. Escarabajos Coprófagos (Scarabaeinae) del Eje Cafetero: Guía para el Estudio Ecológico; WCS-Colombia, CENICAFÉ y la Federación Nacional de Cafeteros: Caldas, Colombia, 2012; pp. 107-112, ISBN 9789589892756.

39. Martínez-Quintero, B.; Cultid-Medina, C.A.; Rudas-Grajales, J. Método para marcar escarabajos coprófagos (Coleoptera: Scarabaeinae) y su implementación en los Andes de Colombia. Acta Zool. Mex. 2013, 29, 448-451.

40. Halffter, G.; Edmonds, W.D. Nesting Behavior of Dung Beetles (Scarabaeinae), 1st ed.; Man and Biosphere Program-UNESCO: Tlalpan, Distrito Federal, Mexico, 1982. 
41. Zuur, A.F.; Ieno, E.N.; Walker, N.; Saveliev, A.A.; Smith, G.M. Mixed Effects Models and Extensions in Ecology with R, 1st ed.; Springer: New York, NY, USA, 2009; pp. 209-259, ISBN 9780387874586.

42. Buckley, Y.M. Generalized linear models. In Ecological Statistics: Contemporary Theory and Application, 1st ed.; Fox, G.A., Negrete-Yankelevich, S., Sosa, V.J., Eds.; Oxford University Press: Oxford, UK, 2015; pp. 131-147, ISBN 978019967255.

43. Burnham, K.P.; Anderson, D.R. Model Selection and Multimodel Inference: A Practical Information-Theoretic Approach, 2nd ed.; Springer: New York, NY, USA, 2002; pp. 66-67, ISBN 0387953647.

44. R Core Team. R: A Language and Environment for Statistical Computing; R foundation for Statistical Computing: Vienna, Austria, 2015.

45. Wilson, K.; Hardy, I.C.W. Statistical analysis of sex ratios: An introduction. In Sex Ratios: Concepts and Research Methods, 1st ed.; Hardy, I.C.W., Ed.; Cambridge University Press: New York, NY, USA, 2002; pp. 48-92, ISBN 978052181896.

46. Ancona, S.; Dénes, F.V.; Krüger, O.; Székely, T.; Beissinger, S.R. Estimating adult sex ratios in nature. Philos. Trans. R. Soc. Lond. B Biol. Sci. 2017, 372, 20160313. [CrossRef]

47. Jolly, G.M. Explicit estimates from capture-recapture data with boht death and immigration stochastic model. Biometrika 1965, 1, 225-247. [CrossRef]

48. Seber, G.A. A note on the multiple-recapture census. Biometrika 1965, 52, 249-259. [CrossRef] [PubMed]

49. Allen, K.A.; Thompson, D.J. Population size y survival estimates for the rare damselflies, Coenagrion mercuriale and Ischnura pumilio. Insect Conserv. Divers. 2014, 7, 241-251. [CrossRef]

50. Fox, J.; Weisberg, S. An R Companion to Applied Regression, 2nd ed.; SAGE Publication: Thousand Oaks, CA, USA, 2011; pp. 229-328, ISBN 978412975148.

51. Hanski, I.; Cambefort, Y. Dung Beetle Ecology, 1st ed.; Princeton University Press: Princeton, NJ, USA, 1991; pp. 179-229, ISBN 0691087393.

52. Huerta, C.; Halffter, G.; Halffter, V. Nidification in Eurysternus foedus Guérin-Méneville: Its relationship to other dung beetle nesting patterns (Coleoptera: Scarabaeidae, Scarabaeinae). Folia Entomológica Mexicana 2005, 44, 74-84.

53. Huerta, C.; Anduaga, S.; Halffter, G.; Portillo-Lopez, J. Use of food and space by tunneler dung beetles (Coleoptera; Scarabaeinae) during reproduction. Environ. Entomol. 2010, 39, 1165-1169. [CrossRef] [PubMed]

54. Janzen, D.H. Seasonal change in abundance of large nocturnal dung beetles (Scarabaeidae) in a Costa Rican deciduous forest and adjacent horse pasture. Oikos 1983, 41, 274-283. [CrossRef]

55. Andresen, E. Effects of season and vegetation type on community organization of dung beetles in a tropical dry forest. Biotropica 2005, 37, 291-300. [CrossRef]

56. Halffter, G.; Matthews, E.G. The Natural History of Dung Beetles of the Subfamily Scarabaeinae (Coleoptera, Scarabaeidae), 1st ed.; Folia Entomol. Mex.: Mexico, Distrito Federal, Mexico, 1966.

57. Bang, H.S.; Crespo, C.H.; Na, Y.E.; Han, M.S.; Lee, J.H. Reproductive development and seasonal activity of two Korean native Coprini species (Coleoptera: Scarabaeidae). J. Asia Pac. Entomol. 2008, 11, 195-199. [CrossRef]

58. Davis, A.L.; Swemmer, A.M.; Scholtz, C.H.; Deschodt, C.M.; Tshikae, B.P. Roles of environmental variables and land usage as drivers of dung beetle assemblage structure in mopane woodland. Austral Ecol. 2014, 39, 313-327. [CrossRef]

59. Sánchez-de-Jesús, H.A.; Arroyo-Rodríguez, V.; Andresen, E.; Escobar, F. Forest loss and matrix composition are the major drivers shaping dung beetle assemblages in a fragmented rainforest. Landsc. Ecol. 2016, 31, 843-854. [CrossRef]

60. Alvarado, F.; Andrade, E.R.; Santos, B.A.; Prescott, G.; Souza, G.; Escobar, F. Forest cover is more important than farmland heterogeneity and livestock intensification for the retention of dung beetle phylogenetic diversity. Ecol. Indic. 2018, 93, 524-532. [CrossRef]

61. Silva, P.G.; Hernández, M.I.M. Spatial patterns of movement of dung beetle species in a tropical forest suggest a new trap spacing for dung beetle biodiversity studies. PLoS ONE 2015, 10, e0126112. [CrossRef] [PubMed]

62. Joseph, H.C. El Pinotus torulosus Eschsch. Rev. Chil. Hist. Nat. 1929, 33, 31-46.

63. Oberholzer, J.J. A description of the third-stage larva of Onitis caffer Bohem. (Copridae: Col.) with notes on its biology. S. Afr. J. Agric. Sci. 1958, 1, 415-422. 
64. Edwards, P.B. Field ecology of a brood-caring dung beetle Kheper nigroaeneus - habitat predictability and life history strategy. Oecologia 1988, 75, 527-534. [CrossRef] [PubMed]

65. Paschalidis, K.M. The Genus Sisyphus Latr (Coleoplera, Scarabaeidae) in Southern Africa. Master's Thesis, Rhodes University, Grahamstown, South Africa, 1975.

66. Tyndale-Biscoe, M. Physiological age-grading in females of the dung beetle Euoniticellus intermedius (Reiche) (Coleoptera: Scarabaeidae). Bull. Entomol. Res. 1978, 68, 207-217. [CrossRef]

67. Charnov, E.L.; Los-den Hartogh, R.L.; Jones, W.T.; van den Assem, J. Sex ratio evolution in a variable environment. Nature 1981, 289, 27-33. [CrossRef] [PubMed]

68. Veran, S.; Beissinger, S.R. Demographic origins of skewed operational and adult sex ratios: Perturbation analyses of two-sex models. Ecol. Lett. 2009, 12, 129-143. [CrossRef]

69. Székely, T.; Weissing, F.J.; Komdeur, J. Adult sex ratio variation: Implications for breeding system evolution. J. Evol. Biol. 2014, 27, 1500-1512. [CrossRef]

70. Wilson, E.O. Sociobiology: The New Synthesis; Harvard University Press: Cambridge, UK, 1975; ISBN 9780674002357.

71. Bessa-Gomes, C.; Legendre, S.; Clobert, J. Allee effects, mating systems and the extinction risk in populations with two sexes. Ecol. Lett. 2004, 7, 802-812. [CrossRef]

72. Moczek, A.P. The behavioral ecology of threshold evolution in a polyphenic beetle. Behav. Ecol. 2003, 6, 841-854. [CrossRef]

73. Pomfret, J.C.; Knell, R.J. Crowding, sex ratio y horn evolution in a South African beetle community. Proc. $R$. Soc. Lond. B Biol. Sci. 2008, 275, 315-321. [CrossRef] [PubMed]

74. Arellano, L.; León-Cortés, J.L.; Ovaskainen, O. Patterns of abundance and movement in relation to landscape structure: A study of a common scarab (Canthon cyanellus cyanellus) in Southern Mexico. Landsc. Ecol. 2008, 23, 69-78. [CrossRef]

75. Villada-Bedoya, S.; Cultid-Medina, C.A. Estructura poblacional de dos especies de Dichotomius Hope, 1838 (Coleoptera: Scarabaeinae) en un paisaje cafetero de Los Andes Occidentales de Colombia, Risaralda. Boletín Científico-Museo de Historia Natural 2017, 21, 188-198. [CrossRef]

76. Barretto, J.W.; Cultid-Medina, C.A.; Escobar, F. Spatial distribution and movement of two dung beetle species (Coleoptera: Scarabaeinae) in a human-modified landscape. Manuscript in preparation.

77. Samways, J.; McGeoch, A.M.; New, T.R. Estimating population size and condition. In Insect Conservation: Approaches and Methods, 1st ed.; Samways, J., McGeoch, A.M., New, T.R., Eds.; Oxford University Press Inc.: New York, NY, USA, 2010; pp. 161-206, ISBN 9780199298235.

78. Hanski, I. Epilogue. In Dung Beetle Ecology, 1st ed.; Hanski, I., Cambefort, Y., Eds.; Princeton University Press: Princeton, NJ, USA, 1991; pp. 366-371, ISBN 0691087393. 